\title{
Impact of Sand Mining and Sea Reclamation on the Environment and Socioeconomic Activities of Ikate and Ilubirin Coastal Low Income Communities in Lagos Metropolis, Southwestern Nigeria
}

\author{
Mynepalli Kameswara Chandra Sridhar, Godson Rowland Ewa Ekpenyong Ana, \\ Temitope Ayodeji Laniyan*
}

Department of Environmental Health Sciences, Faculty of Public Health, College of Medicine, University of Ibadan, Ibadan, Nigeria

Email: *ttlaniyan@gmail.com

How to cite this paper: Sridhar, M. K. C., Ana, G. R. E. E., \& Laniyan, T. A. (2019). Impact of Sand Mining and Sea Reclamation on the Environment and Socioeconomic Activities of Ikate and Ilubirin Coastal Low Income Communities in Lagos Metropolis, Southwestern Nigeria. Journal of Geoscience and Environment Protection, 7, 190-205.

https://doi.org/10.4236/gep.2019.72013

Received: January 14, 2019

Accepted: February 25, 2019

Published: February 28, 2019

Copyright $\odot 2019$ by author(s) and Scientific Research Publishing Inc. This work is licensed under the Creative Commons Attribution International License (CC BY 4.0).

http://creativecommons.org/licenses/by/4.0/

\section{(c) (i) Open Access}

\begin{abstract}
Land reclamation is gradually posing negative impact on man due to unplanned urbanization. A study was carried out on impact of land reclamation through sand mining of coastal communities in Ikate and Ilubirin in Lagos, Nigeria. Ten waters (8 surface and 2 groundwater sources), 10 soil samples and air were collected and taken for analysis. Results of water revealed concentrations lower than WHO (2017) and SON (2007) standards. Soil/sediment with average crustal value revealed $\mathrm{Pb}$ and $\mathrm{Cd}$ above standard values, which is attributed to anthropogenic influence on soils. Quality of air in the study was mainly particulate matter arising from the sea and reclaimed land in the surroundings of the environment with the highest Total Suspended Particulate of $0.8 \mathrm{mg} / \mathrm{m}^{3}$ in sulfur dioxide. This explains corrosion found on the roofs of the communities. Therefore, in the development planning adequate precautions should be put in place to avert environmental degradation.
\end{abstract}

\section{Keywords}

Land Reclamation, Coastal Areas, Sand Mining, Environmental Impact, Water Quality, Air Pollution

\section{Introduction}

Land filling or reclamation is an act of changing the natural state of a land to another form which makes it more useful to man. Reclamation of land began in 
the twelfth and thirteenth century in the Netherlands where a vast area of the land is below the sea level, the struggle to posses these lost lands actually became wide known in the sixteenth century (Hoeksema, 2007; Mulder et al., 1994). Land reclamation is always preferred in areas where construction, mining, agricultural development are found and also areas where wetland is to be developed into habitable and economically viable lands. The Netherlands, Bombay, Hong Kong and several others are typical examples of countries or areas were land reclamation occur. This process literally aids in the expansion of such cities and subsequently makes expansion of the cities possible for more useful purposes. This paper provides an introduction to the history of land reclamation in the Netherlands by describing three important stages in the development of land drainage and reclamation technologies.

Aside the afore mentioned reasons land reclamation can also be done on lands that lacks enough rain, and on lands that have become saline, like beaches and Lagoon environment. A desert can also be reclaimed to a land filled with water by providing water and soil stability. Land reclamation has been practiced since the twentieth century, and the process is still being carried onto date (Ritchiewiki \& Wales, 2006; Environmental Reclamation, 2008).

Other areas where land reclamation has occurred are Asia, Europe, Africa, America and many other countries (Awosika \& Papineau, 1993; Wallis, 1996; Ratcliffe, 1997, USA Today, 2006; Mumbai, 2016; Borzée et al., 2017; Oxford Business Group, 2018). Reclamation of land usually affects the ecosystem which includes the air, water; soil either positively or negatively, consequently affects the human health in those areas.

Sand constitute basically of gravel, which has three distinct layers over laying the deposit, these are: topsoil, subsoil, and overburden with varying thicknesses and quality. Topsoil the dark soil layer directly after surface litter layer. The black color is from accumulation of organic matter that comes from decomposition of dead/decayed plants, it serves as a major nutrient for many vegetables (Lugo et al., 1993; Surender, 2010).

Topsoil, in which sand and precious minerals exist, is an important component for diverse ecological systems such as growth of vegetables, provision of warmth for crustacean animals such as crocodiles, gharries, protection against strong tidal waves and storms, and manufacturing of abrasive and concretes. Removal of this layer in the name of reclamation without leaving the topsoil basically with open pit method, from beaches, inland dunes, or dredges from ocean and river beds leads to deficiency in the nutrients needed for growth of vegetables that could be of use to man, erosion, flooding of beachside communities that invariably led to extinction of animals that depend on sandy beach, and invariable affects public health. This also leads to severe damage of the environment and ecosystems. The processes also cause threats to plants and various animals found on it, some creatures even gets suffocated in the act; it can also change path of rivers which invariably leads to its dryness. A researcher de- 
scribed sand mining as being damaging because it increases coastal erosion and brings in artificial structures that block the flow of sand in the seas (Ghose, 1989; Ashraf et al., 2010; Ashraf et al., 2011; Archive, 2012; Mills \& Staats, 2016; Naples Daily News, 2017).

The Lagoon areas in Lagos, Nigeria harbors 40\% (that is approximately 12 million people) of the population (estimated to be over 18 million) with part of the community being Ikate and Ilubirin. The area has experienced the most destructive environmental hazards which are floods and coastal erosion (Folorunshom, 1999). The study was carried out to evaluate the environmental impact assessment of Ikate and Ilubirin communities when reclamation for a posh housing estate was planned.

\section{Methodology}

\subsection{Study Design}

The study is cross sectional and experimental in nature involving physical and socioeconomic impacts of sand mining and reclamation.

\subsection{The Study Area}

Amongst the 36 States in Nigeria, Lagos is the smallest state, yet the most populous and economically vibrant city. The city is bounded on the north and east by Ogun state; the city shares boundary with Republic of Benin to the west and the Atlantic Ocean behind the Southern borders. Of the over $3000 \mathrm{Ha}$ of estimated landmass, $22 \%$ of it is Lagoons and creeks. Lagos lagoon located around $6^{\circ} 26^{\prime} \mathrm{N}-37^{\prime} \mathrm{N} ; 3^{\circ} 23^{\prime} \mathrm{E}-4^{\circ} 20^{\prime} \mathrm{E}$ (Figure 1) covers about $700 \mathrm{~km}^{2}$, of the whole land of Lagos, it is drained by four main rivers Ogun, Agboyi, Majidun and Aye. The study areas are Ikate (with Elegushi community) and Ilubinrin (Egun settlers) both in Eti-Osa Local Government area of Lagos State. The lagoon complex in Lagos, Nigeria, is part of the Barrier Lagoon system stretching from Cote d'Ivoire to the Niger Delta in Nigeria. It consists of a narrow, low-lying, and sandy beach being is backed by Lagos, Lekki and Ologe lagoons. These lagoons are linked together by many tortuous creeks. Coastal erosion and flooding constitute two of the most devastating environmental hazards affecting this barrier system which harbor about $40 \%$ of the urban population, about 12 million people (Folorunshom, 1999). Some of the areas found around the lagoon are Elegushi and Ilubirin. These are located in Eti-Osa Local Government area in Lekki-pennisulla. Elegushi has over 20,000 population (middle to low income groups) are engaged in some form of trading and vocational activities. The area has Lagos-Epe road to the West and lagoon/sea to the East, the area has over 150 Hectares of land for reclaiming, while Ilubirin a hamlet is on the other side of Elegushi and occupies about 36 Hectares. The area falls within southern part of Dahomey Basin and west edge of Niger Delta. The area is made up of sand (Figure 2) and gastropods shells embedded within the sand, silt and clay beds which represent recent deltaic sediments of Quaternary period. The area experiences a 


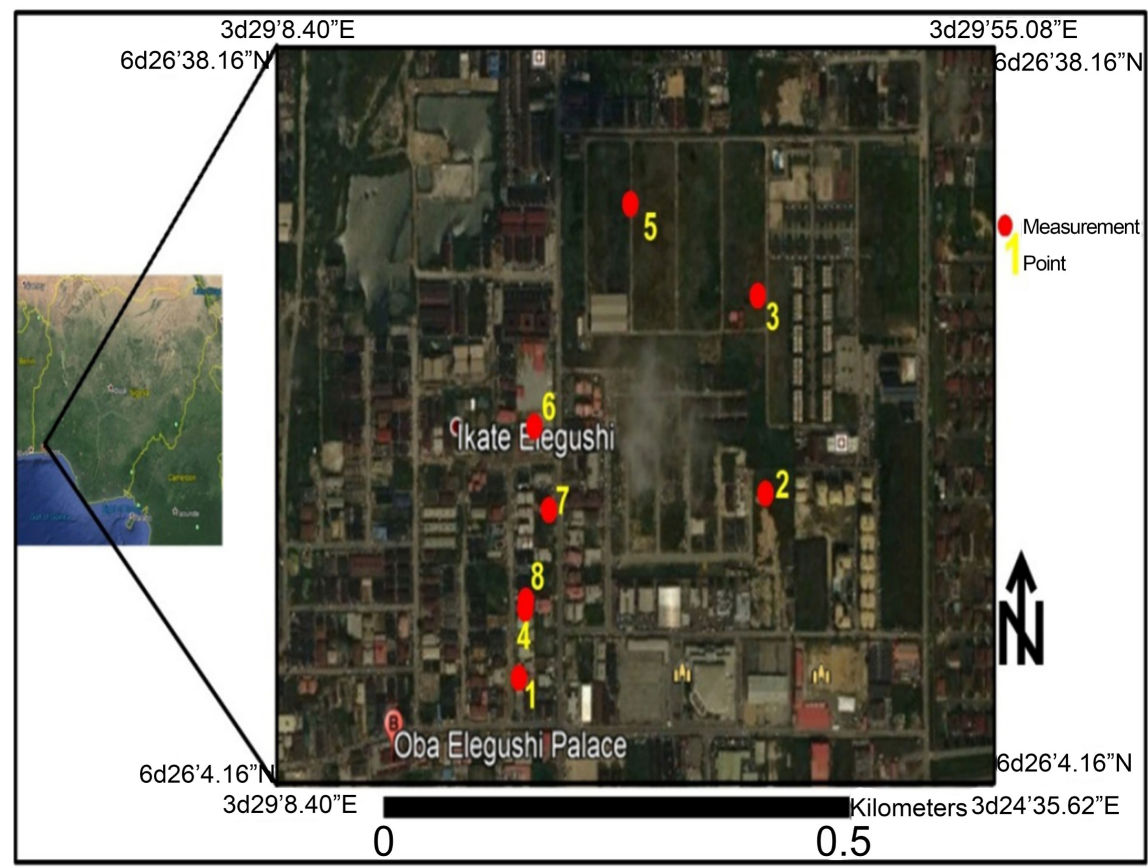

Figure 1. Location of the Study area.

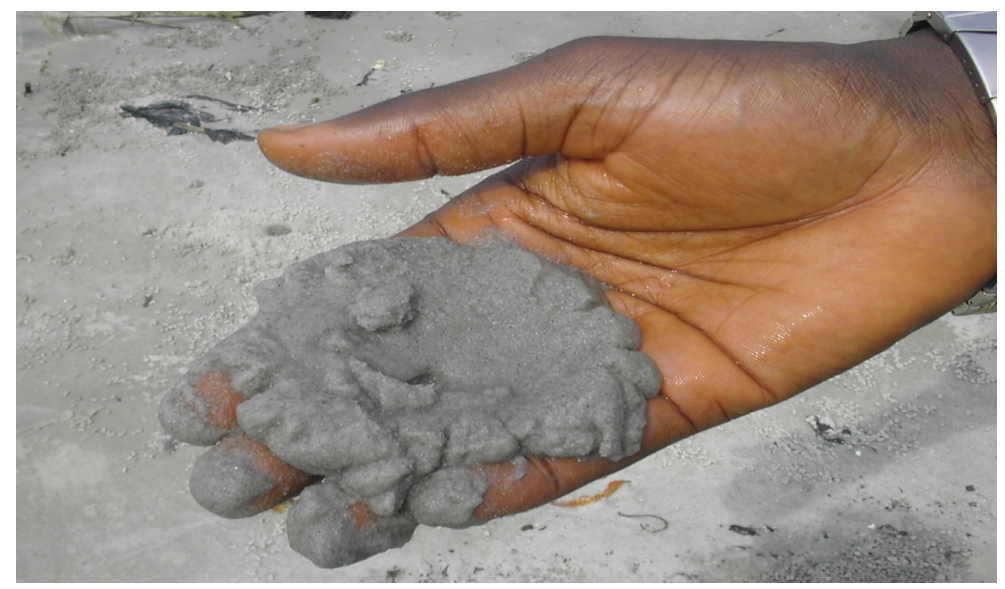

Figure 2. Sand mining at the study site, Lekki.

usual dry and wet season. Tides in Lagos lagoon derive their energy from the ocean and are semi-diurnal in nature with two unequal amplitude and a relatively stable temperature (Hill \& Webb, 1958; Isebor et al., 2005).

\subsection{Period of Sampling}

Samples were picked at the dry season to avoid or reduce the rate of metal dilution. Few samples were picked as representative samples for both Ikate Elegushi and Ilubirin, the result explained what the effect of land reclamation does to the environment.

\subsubsection{Method of Sampling}

Ten water samples ( 8 surface and 2 groundwater) and 10 soil samples were col- 
lected in the area. Soil samples were collected using a rubber spatula to avoid contamination into a cellophane bag, firmly tied, grounded, homogenous and dried at room temperature and sieved with the smallest size sieve $(65 \mu \mathrm{m})$ to get the silt size for the sand before it was packed and labeled for analysis. Water samples were collected into clean 1.5 liter pet bottles, stored in cool box until taken to the laboratory for analyses. Water samples were analyzed for $\mathrm{pH}$, alkalinity, hardness, chloride, Electrical conductivity, turbidity, total dissolved solids, Total suspended solids, Dissolved Oxygen, salinity, minerals like sodium, potassium, and anions such as, ammonia, chloride, sulphate, nitrate, phosphate with all Heavy metals: lead, iron, zinc, and manganese were analyzed for using Titrimetry, Spectrophotometry and other techniques. Total coliforms and Escherichia coli were detected and enumerated using the MPN technique. Air quality was assessed in situ, using appropriate field kits standardized with pure chemicals supplied by Crowncon Detection Instruments Limited/John Lanig International Ltd., UK; Gasman Stock CO/374 (Serial No. 19277A; 0 - 150 range), and CO1-376; Serial No. 19507; 0 - 50 range Ambient temperatures and the environmental sample temperatures were measured using a standard thermometer $\left({ }^{\circ} \mathrm{C}\right)$. The levels of Particulates, $\mathrm{H}_{2} \mathrm{~S}, \mathrm{CO}, \mathrm{CH}_{4}, \mathrm{NH}_{3}$, and noise were measured at various periods and during the operation of the machines. Noise was measured using a sound level meter by taking readings at least three times from each location. Sample collection and analyses were carried out according to standard methods (AOAC, 1960; APHA, 2017).

\subsubsection{Geology and Effect on Climate Change}

Ikate and Ilubirin the study area falls within southern edge of Dahomey Basin and the western edge of the Niger Delta. The Quaternary of this area include most recent deltaic sediments which are made up of sand, silt and clay beds. These areas (Ikate and Ilubirin) are dominantly made-up of loose coarse-grained sands, embedded within the sands are gastropods shells. Increase in population that lead to increase in construction using the sand, silt and clay bed to build, construct road, drilling of bore holes had inevitably lead to increased concentration of carbon-dioxide to nearly $30 \%$, increased level of methane to double its amount and increased level of nitrous oxide to over 15\%. All these had enhanced the rate at which heat trap in the atmosphere. Thus, increasing the Global mean sea level and Global warming which invariably increases the melting rates of lacier and ice caps, thereby causing the sea level to rise, with evidence of rise in the sea level with evidence of extreme tides, waves and storm surge. Though the values of sea level rise may seem small, inundation effects of sea level rise by Brunn (1977) show that a sea level rise of $0.3 \mathrm{~m}$ could cause an inundation of more than $35 \mathrm{~m}$.

\section{Results and Discussion}

\subsection{Water Samples}

Comparing the mean values of physical parameters for surface and groundwater 
Table 1. Mean comparison of the Physicochemical Parameters for the Surface and groundwater samples for Ikate and Ilubirin with WHO (2017) \& SON (2007).

\begin{tabular}{ccccccc}
\hline Parameter (mg/L) & Ikate & Ilubirin & GIK & GIL & WHO 2017 & SON 2007 \\
\hline $\mathrm{pH}$ & 6.87 & 6.57 & 6.93 & 6.7 & $6.5-8.5$ & $6.5-8.6$ \\
Colour & 34.75 & 26.5 & 14 & 52 & - & 15 \\
Turbidity & 4.75 & 5.5 & 2 & 11 & - & 5 \\
Total hardness & 398 & 493 & 104 & 120 & - & 150 \\
$\mathrm{Cl}^{-}$ & 10,000 & 12,000 & 1150 & 1300 & 250 & 250 \\
$\mathrm{SO}_{3}^{-}$ & 2488.8 & 3432.3 & 107.1 & 99.45 & 500 & 100 \\
$\mathrm{DO}^{-}$ & 2.75 & 1.13 & 0.3 & 0.9 & - & - \\
Conductivity & 2860.25 & 2970.5 & 899 & 704 & 1400 & - \\
$\mathrm{TSS}^{\mathrm{T}}$ & 1.75 & 2.25 & 1 & 1 & - & - \\
$\mathrm{TDS}^{2}$ & 1859.25 & 1930.75 & 584 & 458 & 500 & 500 \\
$\mathrm{NO}_{3}^{-}$ & 2.09 & 13.51 & 55.55 & 50.26 & 50 & 50 \\
$\mathrm{PO}_{3}^{-}$ & $\mathrm{ND}$ & $\mathrm{ND}$ & $\mathrm{ND}$ & $\mathrm{ND}$ & - & - \\
Total coliforms & 25 & 115 & 0 & 0 & 0 in $100 \mathrm{~mL}$ & 10 \\
E. coli & 0 & 90 & 0 & 0 & 0 in $250 \mathrm{~mL}$ & 0 \\
\hline
\end{tabular}

Notes: GIK-Groundwater Ikate; GIL-Groundwater Ilubirin.

samples in the study area with WHO (2017) and SON (2007) Table 1, revealed that $\mathrm{pH}$ is within the permissible limits, while colour, turbidity, total hardness were found to be high as per SON (2007) in both the surface and groundwater of the study area, EC and TDS were observed to be high in the surface water of both Ikate and Ilubirin but low in the groundwater. Nitrate $\left(\mathrm{NO}_{3}\right)$, Escherichia $E$-coli was observed to be very high in the surface water of Ilubirin, while nothing was observed for Ikate and the groundwater. The total coliform in surface water of Ikate and Ilubirin was noticed to be well above the permissible standard while the groundwater did not reveal any evidence of total coliform. The channel for the water body of the lagoon is natural while the observed water column to bed ranges from 0.5 to $17 \mathrm{~m}$. The water body is characterized by a slow tidal waves often drifting in the northward direction. All surface water samples collected are colourless with a temperature range of $24^{\circ} \mathrm{C}-27^{\circ} \mathrm{C}$ (Table 1). This water could be said to be saline considering the high TDS $(>10,000 \mathrm{mg} / \mathrm{l})$ and electrical conductivity $(20.0 \mathrm{mS} / \mathrm{cm})$. It should be noted that extremely high conductivity value for water samples from Ilubinrin revealed the brackish nature of the water body. The groundwater samples are generally colourless relatively low TDS but high electrical conductivity $(\max 1633 \mathrm{mS} / \mathrm{cm}$ ). The static water level in most of the wells observed is to a maximum of $1.2 \mathrm{~m}$ especially in Ikate. All the metal contents were found lower than the WHO (2017) and SON (2007) with the exception of $\mathrm{Mn}$ in Ilubirin (Table 2). The metallic ions concentrations in the water samples are generally low. The concentration of $\mathrm{Mn}$ ranges from $0.00-0.74 \mathrm{mg} / \mathrm{l}, \mathrm{Fe} 0.19-0.27 \mathrm{mg} / \mathrm{l}, \mathrm{Zn} 0.08-0.44 \mathrm{mg} / \mathrm{l}, \mathrm{Cd} 0.050-0.052 \mathrm{mg} / \mathrm{l}$ 
Table 2. Mean Comparison of the Metal values for the Surface and groundwater samples for Ikate and Ilubirin with WHO (2017) \& SON (2007).

\begin{tabular}{cccccc}
\hline Samples & $\mathrm{Mn}(\mathrm{mg} / \mathrm{l})$ & $\mathrm{Fe}(\mathrm{mg} / \mathrm{l})$ & $\mathrm{Zn}(\mathrm{mg} / \mathrm{l})$ & $\mathrm{Pb}(\mathrm{mg} / \mathrm{l})$ & $\mathrm{Cd}(\mathrm{mg} / \mathrm{l})$ \\
\hline Ikate & 0.47 & 0.24 & 0.19 & 0 & 0.05 \\
Range & $0.00-0.74$ & $0.19-0.27$ & $0.08-0.44$ & 0 & $0.050-0.052$ \\
Ilubirin & 0.62 & 0.24 & 0.13 & 0.053 & 0.08 \\
Range & $0.49-0.79$ & $0.18-0.31$ & $0.09-0.17$ & $0.00-0.21$ & $0.07-0.09$ \\
GIK & 0.59 & 0.19 & 0.10 & 0.00 & 0.000 \\
GIL & 0.61 & 0.24 & 0.13 & 0.00 & 0.000 \\
range & $0.59-0.61$ & $0.19-0.24$ & $0.10-0.13$ & 0 & 0 \\
WHO (2017) & 0.05 & 0.5 & 3 & 0.01 & 0.0001 \\
SON (2007) & 0.2 & 0.3 & 3 & 0.01 & 0.003 \\
\hline
\end{tabular}

while $\mathrm{Pb}$ was not detected in the surface water samples obtained from Ikate. At Ilubinrin the $\mathrm{Mn}$ content ranges from $0.49-0.79 \mathrm{mg} / \mathrm{l}, \mathrm{Fe} 0.018-0.31 \mathrm{mg} / \mathrm{l}, \mathrm{Zn}$ $0.09-0.17 \mathrm{mg} / \mathrm{l}, \mathrm{Pb} 0.00-0.21 \mathrm{mg} / \mathrm{l}$ and $\mathrm{Cd} 0.073-0.086 \mathrm{mg} / \mathrm{l}$ respectively. Generally the metal contents of the surface water at Ikate and Ilubirnrin were within the permissible level. The two groundwater samples collected were from Ikate and the metallic ions revealed that $\mathrm{Mn}$ ranges from $0.59-0.61 \mathrm{mg} / \mathrm{l}, \mathrm{Fe}$ $0.19-0.24 \mathrm{mg} / \mathrm{l}, \mathrm{Zn} 0.10-0.13 \mathrm{mg} / \mathrm{l}, \mathrm{Pb}$ and $\mathrm{Cd}$ were not detected in groundwater samples. The current level of metal concentrations in the water samples (surface and groundwater) are generally low and represent the baseline conditions.

\subsection{Soil Samples}

Grain sizes are uniformly distributed in sand, and are medium grained sand with relatively no evidence of clay materials in the sand, thus, using AASHO (1978) descriptions modified after Hogentogler and Terzaghi (1945) (Holtz \& Kovacs, 1981) classification, the soil can be described as good sub grade material. Maximum dry density of the composite soil sample is $1.80 \mathrm{mg} / \mathrm{Cu} . \mathrm{m}$ and the minimum dry density is $1.72 \mathrm{mg} / \mathrm{Cu} . \mathrm{m}$ while the optimum moisture content is $14 \%$. These results indicate that the soils have low plasticity index and very high sand content. The high density will enhance the structural properties of the soils, reduce the water absorption tendencies and ensure improved resistance (Figure 3 and Figure 4).

The Lagoon sediments and soils of the two areas are generally sandy, extremely low in organic matter and slightly acidic in nature. Comparison of the metal contents with the Average Crustal Value (ACV) helps to evaluate the nature of the soil/sediments of the environment and it revealed that $\mathrm{Pb}$ and $\mathrm{Cd}$ are far above the standard (Table 3). This may be attributed to the introduction of these metals into the soils of the areas via anthropogenic sources. At the time of these study Nigerian petroleum products contained lead used in the refining process and automobile usage is very high in the megacity. The other metals 


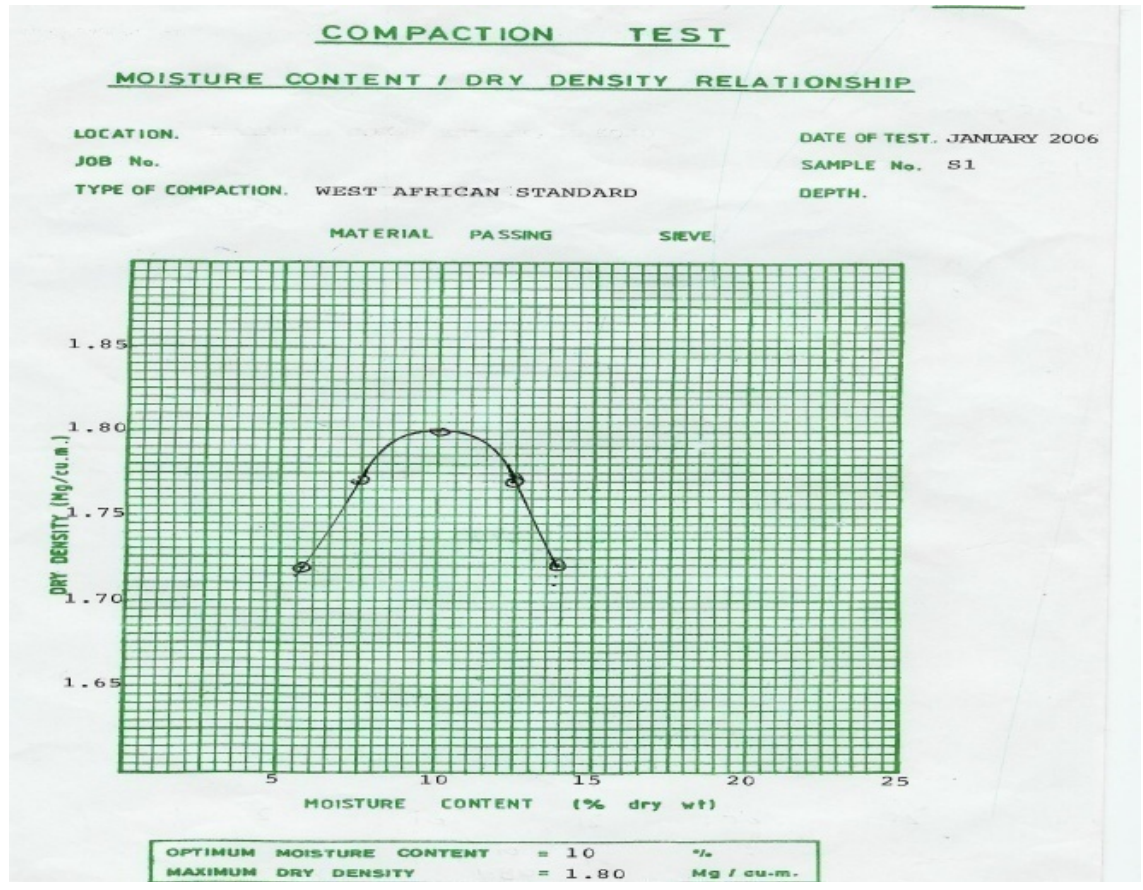

Figure 3. Moisture content of the soil at Ikate.

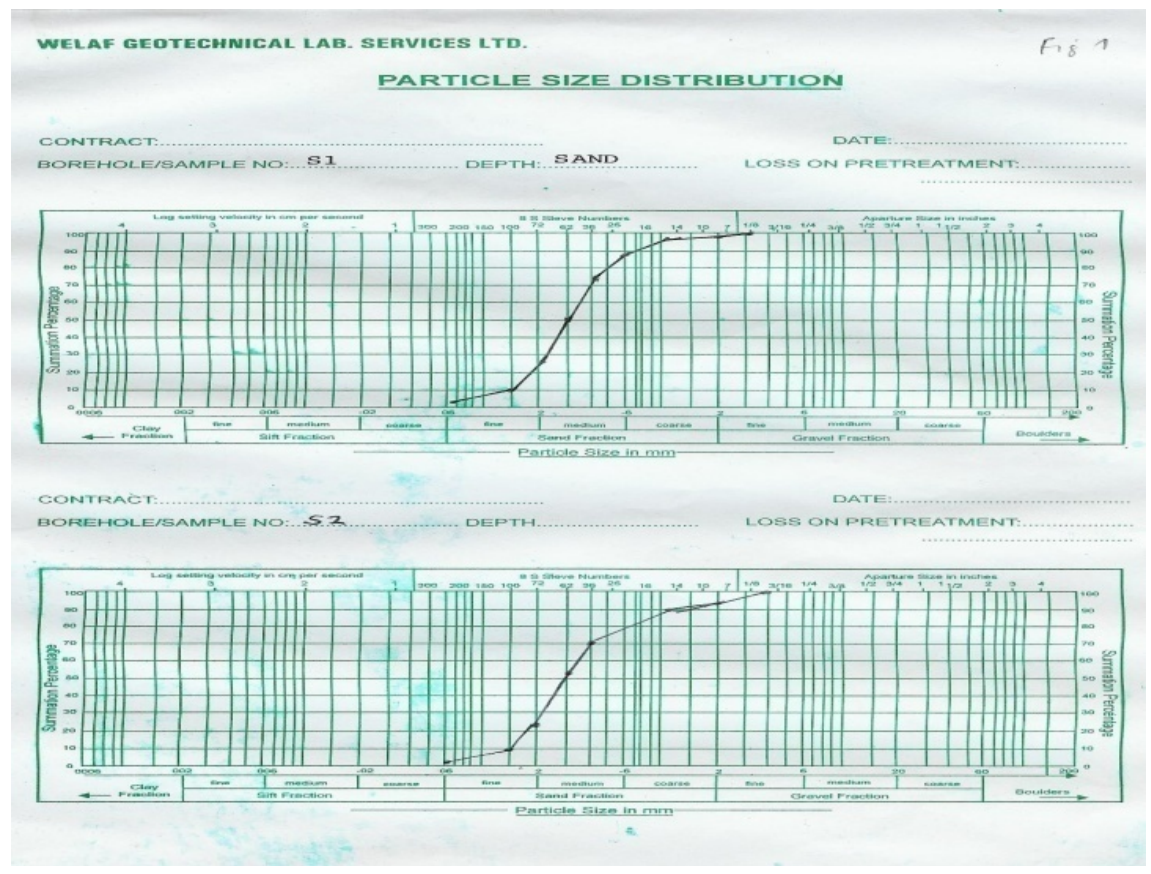

Figure 4. Particle size distribution of the soils.

however showed very low values when compared with average crustal values. This is an indication that these metals are within safe limits in the soil of the areas. The generally low level of these metals in the soils of the study areas can also be connected to the sandy nature of the soils and the absence of clay materials and organic matter that could have served as adsorbing surfaces for the metals. The major elements contained in the soils are generally low. 
Table 3. Mean Comparison of the Metal values in the Soils.

\begin{tabular}{|c|c|c|c|c|c|}
\hline LOCATION mg/L & Min & $\operatorname{Max}$ & Mean & Range & Crustal average \\
\hline $\mathrm{pH}\left(\mathrm{H}_{2} \mathrm{O}\right)$ & 6.12 & 8.08 & 7.401 & $6.12-8.08$ & - \\
\hline $\mathrm{OM}$ & 4.16 & 17.01 & 10.167 & $4.16-17.01$ & - \\
\hline Acidity & 0.21 & 0.63 & 0.477 & $0.21-0.63$ & - \\
\hline $\mathrm{Pb}$ & 29.01 & 239.1 & 68.47 & $29.01-239.1$ & 12.5 \\
\hline $\mathrm{Cd}$ & 5.43 & 8.3 & 6.919 & $5.43-8.3$ & 0.2 \\
\hline $\mathrm{Mn}$ & 117.45 & 201.84 & 164.427 & $117.45-201.84$ & 950 \\
\hline $\mathrm{Zn}$ & 8.65 & 17.94 & 11.961 & $8.65-17.94$ & 70 \\
\hline $\mathrm{Cu}$ & 3.37 & 5.41 & 4.399 & $3.37-4.41$ & 5 \\
\hline $\mathrm{Fe}$ & 73.61 & 143.74 & 110.713 & $73.61-143.74$ & - \\
\hline $\mathrm{Ca}$ & 2.99 & 4.17 & 3.573 & $2.99-4.17$ & - \\
\hline $\mathrm{Mg}$ & 2.48 & 3.87 & 3.342 & $2.48-3.87$ & - \\
\hline K & 0.71 & 0.99 & 0.859 & $0.71-0.99$ & - \\
\hline $\mathrm{Na}$ & 0.71 & 1.19 & 0.914 & $0.71-1.19$ & - \\
\hline $\mathrm{N}$ & 0.43 & 1.76 & 1.056 & $0.43-1.76$ & - \\
\hline $\mathrm{P}$ & 4.73 & 28.72 & 13.835 & $4.73-28.72$ & - \\
\hline
\end{tabular}

Table 4. Inter-elemental analysis of the metals.

\begin{tabular}{|c|c|c|c|c|c|c|c|c|c|c|c|c|c|c|c|}
\hline & $\mathrm{pH}$ & $\mathrm{OM}$ & Acidity & $\mathrm{Pb}$ & $\mathrm{Cd}$ & $\mathrm{Mn}$ & $\mathrm{Zn}$ & $\mathrm{Cu}$ & $\mathrm{Fe}$ & $\mathrm{Ca}$ & $\mathrm{Mg}$ & $\mathrm{K}$ & $\mathrm{Na}$ & $\mathrm{N}$ & $\mathrm{P}$ \\
\hline $\mathrm{pH}$ & 1 & & & & & & & & & & & & & & \\
\hline $\mathrm{OM}$ & 0.374 & 1 & & & & & & & & & & & & & \\
\hline Acidity & -0.105 & 0.486 & 1 & & & & & & & & & & & & \\
\hline $\mathrm{Pb}$ & 0.089 & 0.095 & 0.42 & 1 & & & & & & & & & & & \\
\hline $\mathrm{Cd}$ & 0.503 & 0.384 & 0.233 & 0.551 & 1 & & & & & & & & & & \\
\hline $\mathrm{Mn}$ & 0.456 & 0.21 & -0.006 & 0.122 & 0.133 & 1 & & & & & & & & & \\
\hline $\mathrm{Zn}$ & 0.291 & 0.569 & -0.144 & -0.353 & 0.061 & 0.535 & 1 & & & & & & & & \\
\hline $\mathrm{Cu}$ & -0.219 & 0.107 & -0.341 & -0.539 & -0.531 & 0.393 & 0.729 & 1 & & & & & & & \\
\hline $\mathrm{Fe}$ & 0.097 & 0.154 & -0.35 & -0.18 & -0.039 & 0.779 & 0.717 & 0.741 & 1 & & & & & & \\
\hline $\mathrm{Ca}$ & -0.206 & -0.352 & -0.376 & -0.292 & -0.244 & 0.443 & 0.423 & 0.585 & 0.658 & 1 & & & & & \\
\hline $\mathrm{Mg}$ & -0.004 & -0.224 & -0.319 & -0.105 & -0.046 & 0.673 & 0.515 & 0.62 & 0.775 & 0.878 & 1 & & & & \\
\hline $\mathrm{K}$ & 0.008 & 0.248 & 0.101 & 0.078 & -0.133 & 0.809 & 0.636 & 0.682 & 0.794 & 0.623 & 0.764 & 1 & & & \\
\hline $\mathrm{Na}$ & 0.498 & 0.175 & -0.076 & 0.023 & 0.08 & 0.933 & 0.592 & 0.405 & 0.724 & 0.596 & 0.718 & 0.805 & 1 & & \\
\hline $\mathrm{N}$ & 0.38 & 1.000 & 0.497 & 0.095 & 0.382 & 0.214 & 0.561 & 0.098 & 0.147 & -0.355 & -0.229 & 0.247 & 0.18 & 1 & \\
\hline $\mathrm{P}$ & 0.595 & 0.133 & -0.085 & 0.562 & 0.342 & 0.716 & 0.152 & -0.085 & 0.414 & 0.14 & 0.314 & 0.471 & 0.714 & 0.136 & 1 \\
\hline
\end{tabular}

Note: A + 0.5 and above means same source and significant correlation; A - 0.5 and above indicates significant different source.

Inter-elemental analysis as shown in Table 4 of the physicochemical parameters was carried out with the metals, and a strongly positive correlation was observed 
Cd-pH $(\mathrm{r}=0.503), \mathrm{P}-\mathrm{pH}(\mathrm{r}=0.595), \mathrm{Zn}-\mathrm{OM}(\mathrm{r}=0.569), \mathrm{N}-\mathrm{OM}(\mathrm{r}=1.00)$, Fe-Mn $(\mathrm{r}=0.779), \mathrm{K}-\mathrm{Mn}(\mathrm{r}=0.809)$, and $\mathrm{Mg}-\mathrm{Ca}(\mathrm{r}=0.878)$ and this revealed that the elements are from the same anthropogenic sources and this was also confirmed by the dendogram diagram (Figure 5), while a significantly negative correlation was found between $\mathrm{Cu}, \mathrm{Pb}$ and $\mathrm{Cd} \mathrm{Cu}-\mathrm{Pb}(\mathrm{r}=-0.539), \mathrm{Cu}-\mathrm{Cd}(\mathrm{r}=-0.531)$, which implies that the metals are from entirely different source from each other.

\subsection{Air Quality}

A representative air sample was picked in both research area, results in each revealed the impact of land reclamation on the environment.

\subsection{Ikate Elegushi}

The quality of air (Figure 6) in the study area is mainly filled with particulates coming directly from the sea and reclaimed soils of the environment. This therefore, will reflect high corrosion of roofs found in the study area, and those not corroded at the time will surely be affected as the exposure increases. Spatial maps (Figure $7(a)$ ) drew for each parameter revealed highest Total Suspended Particle (TSP) levels $\left(0.8 \mathrm{mg} / \mathrm{m}^{3}\right)$ at locations 6 on the lagoon and location 2 on the reclaimed land respectively. The highest Sulfur dioxide level of $6 \mathrm{ppm}$ was recorded at location 4 on the surface water. Highest ammonia level ( 9 ppm) was recorded on locations 1, 3 and 4 on land. Lastly the highest carbon monoxide level 1 ppm was recorded on location 1 on land. Noise when compared with the permissible level was observed to be tolerable the highest noise level was found on land ( $89.1 \mathrm{dBA})$ in location 1 , followed by $84.6 \mathrm{dBA}$ at location 6 on the lagoon (Table 5).

\subsection{Ilubirin}

Air quality as shown in Figure 6 was perceived to be less tolerable because of

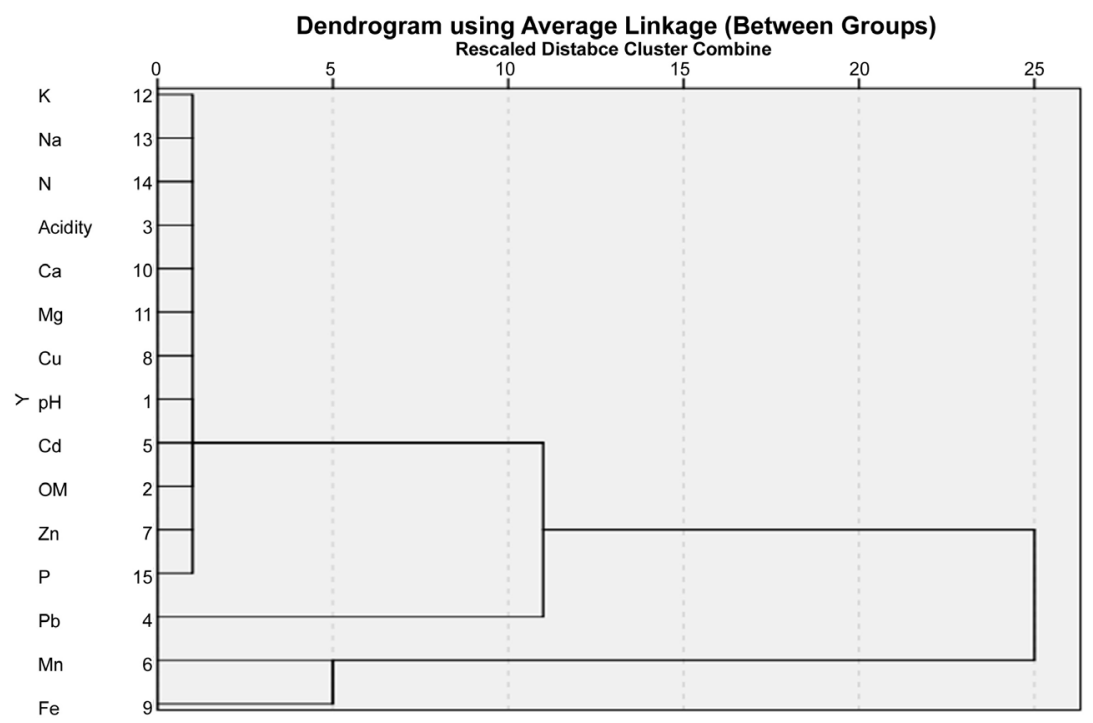

Figure 5. Dendogram Plot for the metals in soil. 

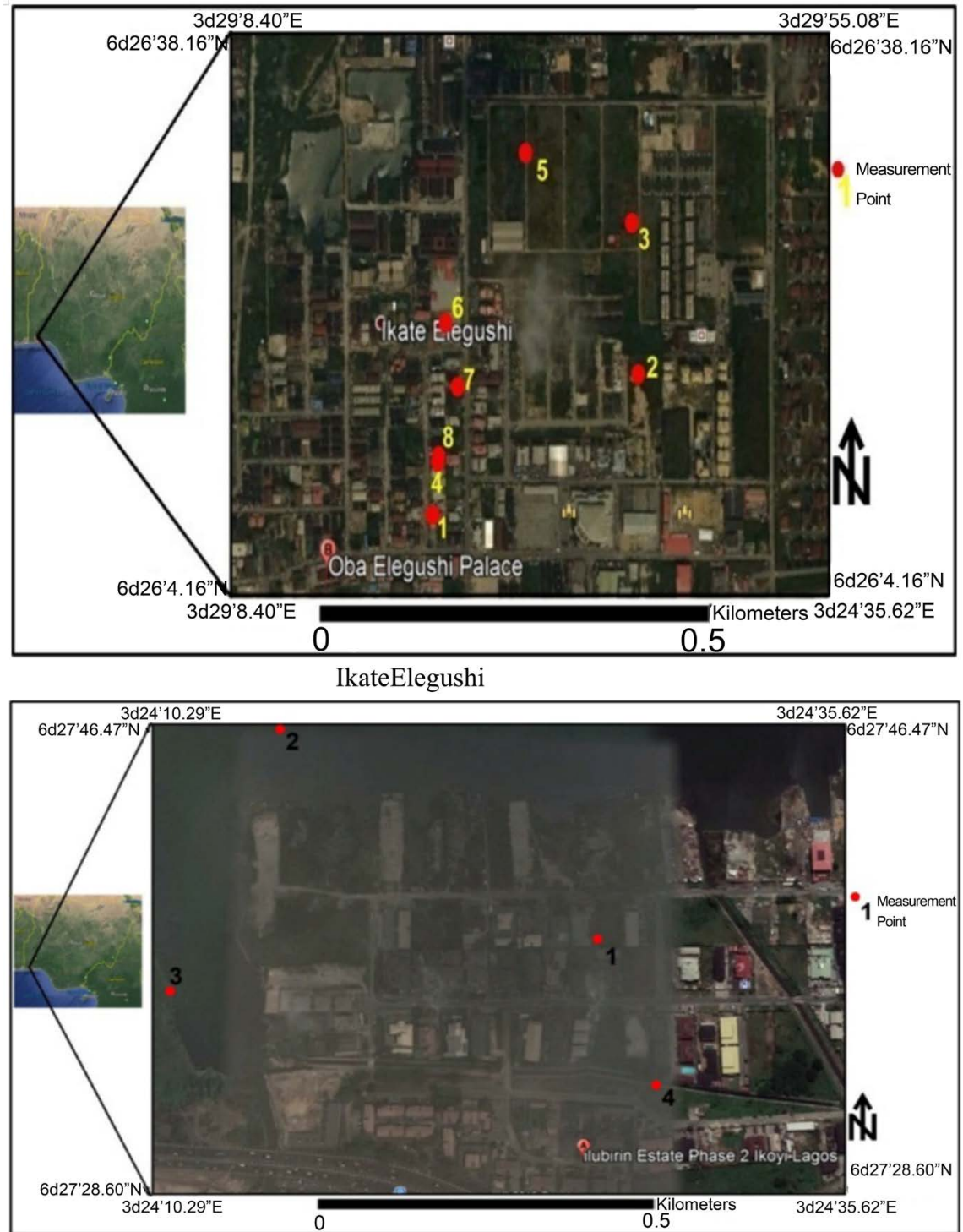

Ilubirin

Figure 6. Areal Map of the location showing Air sampling points.

Table 5. Air quality Data of IkateElegushi.

\begin{tabular}{|c|c|c|c|c|c|c|c|c|}
\hline Parameters & 1 (land) & $4(\mathrm{sw})$ & $2(\mathrm{sw})$ & $6(\mathrm{sw})$ & $8(\mathrm{sw})$ & 2 (land) & 3 (land) & 4 (land) \\
\hline \multirow{2}{*}{ GPS } & $06^{\circ} 26.108 \mathrm{~N} /$ & $06^{\circ} 27.270 \mathrm{~N} /$ & $06^{\circ} 27.611 \mathrm{~N} /$ & $06^{\circ} 27.073 \mathrm{~N} /$ & $06026.828 \mathrm{~N} /$ & $06^{\circ} 26.446 \mathrm{~N} /$ & $06^{\circ} 26.303 \mathrm{~N} /$ & $06^{\circ} 26.146 \mathrm{~N} /$ \\
\hline & $003^{\circ} 29.205 \mathrm{E}$ & $003^{\circ} 29.881 \mathrm{E}$ & $003^{\circ} 28.921 \mathrm{E}$ & $003^{\circ} 28.300 \mathrm{E}$ & $003^{\circ} 29.510 \mathrm{E}$ & $003^{\circ} 29.245 \mathrm{E}$ & $003^{\circ} 29.288 \mathrm{E}$ & $003^{\circ} 29.225 \mathrm{E}$ \\
\hline $\mathrm{TSP} \mathrm{mg} / \mathrm{m}^{3}$ & 0.4 & 0.7 & 0.7 & 0.8 & 1.0 & 0.8 & 0.5 & 0.4 \\
\hline $\mathrm{SO}_{2}(\mathrm{ppm})$ & 0.00 & 6.0 & 0.2 & 0.1 & 0.2 & 0.5 & 0.1 & 0.01 \\
\hline $\mathrm{NO}_{2}(\mathrm{ppm})$ & - & - & - & - & - & - & - & - \\
\hline $\mathrm{NH}_{3}(\mathrm{ppm})$ & 9 & 2 & 5 & 3 & 2 & 5 & 9 & 9 \\
\hline $\mathrm{CO}(\mathrm{ppm})$ & 3 & 1 & 1 & 2 & 2 & 1 & 1 & 1 \\
\hline $\mathrm{CH}_{4}(\mathrm{ppm})$ & - & - & - & - & - & - & - & - \\
\hline Noise (dBA) & 89.1 & 68.9 & 77.1 & 84.6 & 70.9 & 50.2 & 45.5 & 63.5 \\
\hline
\end{tabular}


odor from decaying matter in the water body. The highest TSP level $\left(1.0 \mathrm{mg} / \mathrm{m}^{3}\right)$ was recorded at location 1 on land while the highest sulfur dioxide level $(0.4$ $\mathrm{ppm}$ ) was at location 2 on surface water. Highest ammonia level (8 ppm) was observed at location 1 on land and the highest carbon monoxide level $(2.0 \mathrm{ppm})$ was recorded at location 2 on the surface water, highest noise levels (79.8 dBA in Table 5) were found at location 1 on surface water and location 2 on land. These levels were both lower than the permissible level (90 dBA), and therefore noise was not considered to be a major problem in the area (Table 6 and Figure 7(b)).

\subsection{Comparison of Variations in IkateElegushi and Ilubirin}

The results revealed that IkateElegushi is more prone to pollution which eventually leads to problems in the community than at Ilubirin.

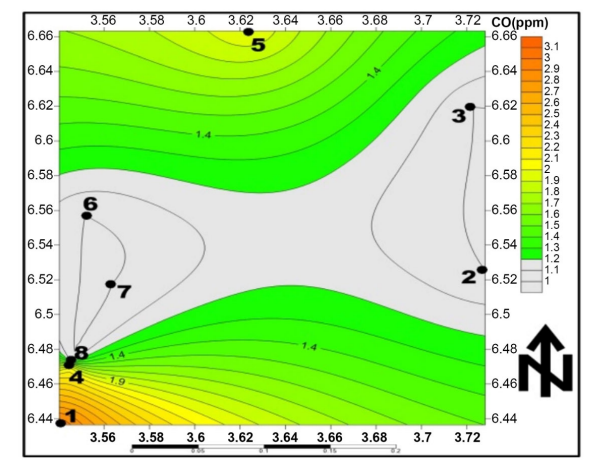

$\mathrm{CO}$

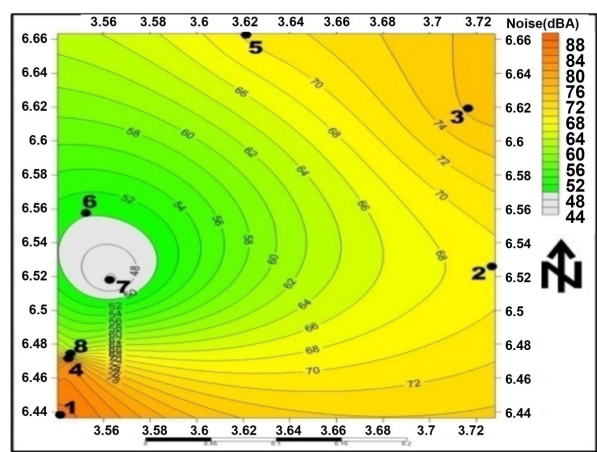

Noise

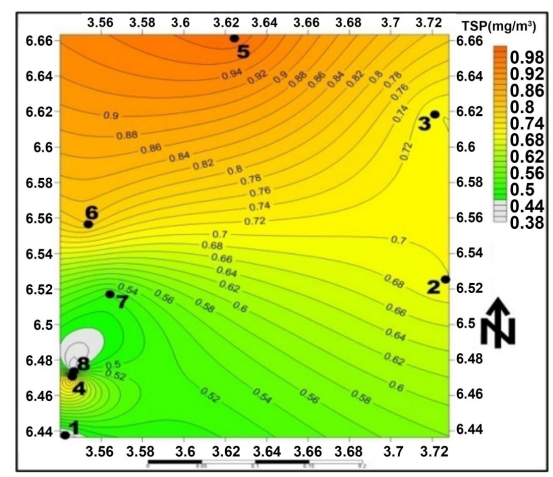

TSP

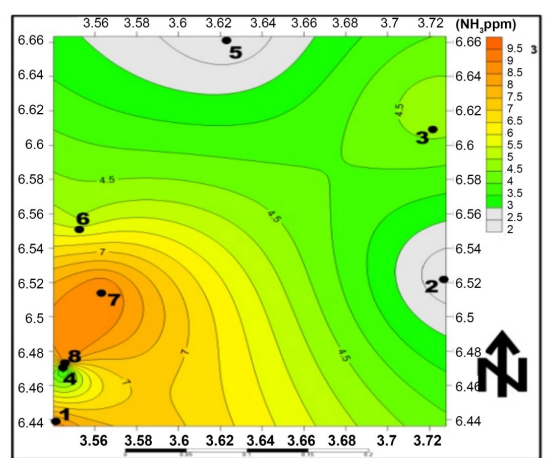

$\mathrm{NH}_{3}$

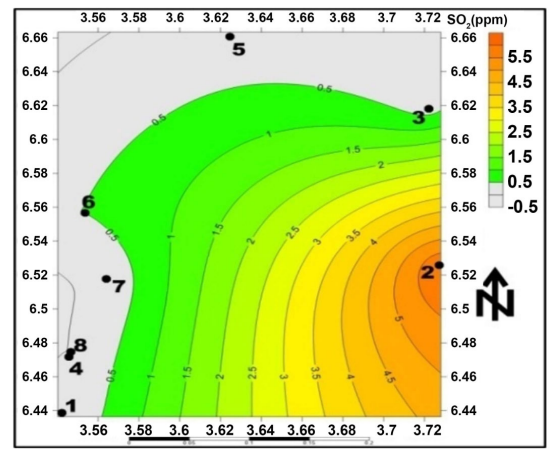

$\mathrm{SO}_{2}^{-}$

(a) 

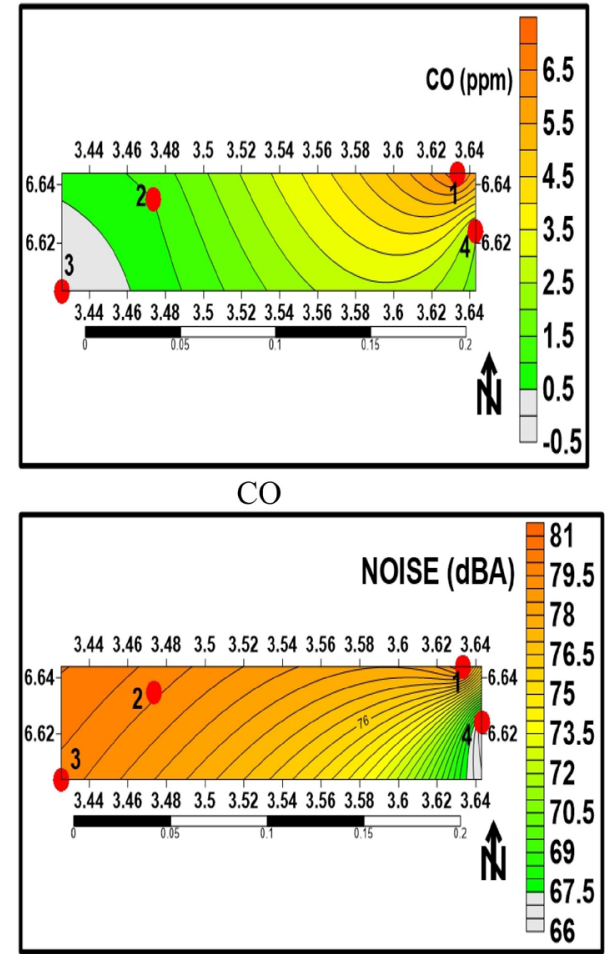

Noise

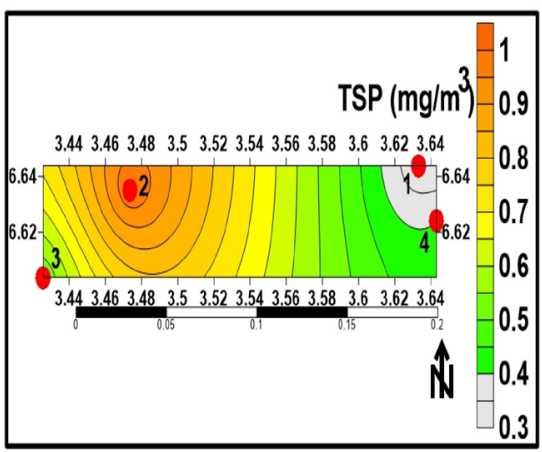

TSP

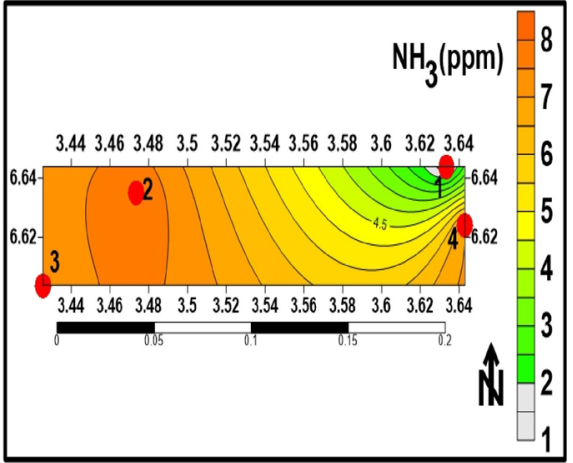

$\mathrm{NH}_{3}$

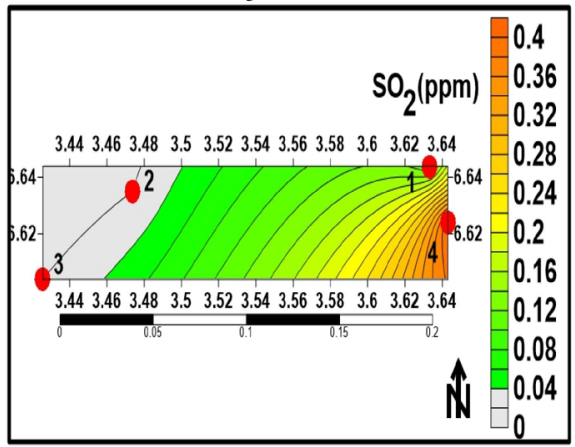

$\mathrm{SO}_{2}$

(b)

Figure 7. (a) Spatial Maps of IkateElegushi; (b) Spatial Maps of Ilubirin.

Table 6. Air quality Data of Ilubirin.

\begin{tabular}{ccccc}
\hline Parameters & 1 (land) & $1(\mathrm{sw})$ & $2(\mathrm{sw})$ & 2 (land) \\
\hline $\mathrm{GPS}$ & $06^{\circ} 27.666 \mathrm{~N} / 003^{\circ} 24.265 \mathrm{E}$ & $06^{\circ} 27.554 \mathrm{~N} / 003^{\circ} 24.092 \mathrm{E}$ & $06^{\circ} 27.627 \mathrm{~N} / 003^{\circ} 23.935 \mathrm{E}$ & $06^{\circ} 27.698 \mathrm{~N} / 003^{\circ} 23.900 \mathrm{E}$ \\
\hline $\mathrm{TSP} \mathrm{mg} / \mathrm{m}^{3}$ & 1.0 & 0.5 & 0.4 & 0.3 \\
$\mathrm{SO}_{2}(\mathrm{ppm})$ & 0.02 & 0.02 & 0.4 & 0.1 \\
$\mathrm{NO}_{2}(\mathrm{ppm})$ & - & - & - & - \\
$\mathrm{NH}_{3}(\mathrm{ppm})$ & 8 & 7 & 7 & 7 \\
$\mathrm{CO}(\mathrm{ppm})$ & 1 & 0.00 & 2 & - \\
$\mathrm{CH}(\mathrm{ppm})$ & - & - & - & 79.8 \\
$\mathrm{Noise}(\mathrm{dBA})$ & 79.6 & 79.8 & 66.0 & - \\
\hline
\end{tabular}


Socioeconomic Impact of Land Reclamation on Ikate Elegushi and Ilubirin

\section{1) IkateElegushi}

The area with estimated population of 20,000 gets their drinking water only from bore holes constructed within the community and this is not sufficient for the area; the only available hand-dug well has become undrinkable due to the influx from the sea and the impact of land reclamation. This therefore, mad most of the community to depend on sachet water which may not be pure invariable leading to Typhoid fever as being one of the common diseases found in the community. Fishing which is the major source of livelihood had being affected and drastic reduction in fish population was found in the community due to increase in human activities.

\section{2) Ilubirin}

The Ilubirin community is made up of mostly squatters numbering well over 500 ; the area is surrounded by large expanse of surface water which is the lagoon. This serves the squatters both domestic and drinking purposes. Apart from the built up area from a previously reclaimed environment which has good residential looking structures, the rest of the area surrounding the proposed reclamation area has huts and shanties occupied by the squatting community who are mostly fishermen. Land reclamation amongst this community is of high impact since their only source of drinking water is the Lagoon tin which they also use as their disposal basin and means of excretion. The community is also experiencing drastic reduction in fish population and the disease found are diverse types of water borne disease.

\section{Conclusion and Recommendations}

The metal levels of Ilubirin water was observed to be more polluted than that of the Ikate environ, while $\mathrm{Pb}$ and $\mathrm{Cd}$ were revealed to be high in the soil/sediments of the two environ all being attributed to high anthropogenic influence on the area. Quality of air in the study was mainly particulate matter from the sea and reclaimed land with high TSP of $0.8 \mathrm{mg} / \mathrm{m}^{3}$ in sulfur dioxide leading to high rate of roof corrosion in the communities.

In line with the growing world, reclamation is a viable option to increase the available land. However, in the development planning adequate precautions should be put in place the possible occurrence of future disasters such as floods, hurricanes and collapse of the buildings. Communities should be taken adequate care as there will be loss of land holding capacity for the indigenes. Any development should be based on collective decision and no section of the community should be left out. Human health along with the ecosystem health should be considered at all levels.

\section{Acknowledgements}

The authors acknowledge the role played by Professor Festus Akinlolu Abimbola, who took part in the field survey. We also thank various field assistants who collected data on the field. 
All necessary corrections were made by all the authors and no contension was found.

\section{Conflicts of Interest}

The authors declare no conflicts of interest regarding the publication of this paper.

\section{References}

AOAC (1960). Official Methods of Analysis (10th ed.). Washington DC: Association of Official Analytical Chemists.

APHA (2017). Standard Methods for the Examination of Water and Wastewater (23rd ed.). Washington DC: American Public Health Association.

Ashraf, M. A., Maah, M. J., \& Yusoff, I. B. (2010). Study of Water Quality and Heavy Metals in Soil \& Water of Ex-Mining Area Bestari Jaya, Peninsular Malaysia. International Journal of Basic \& Applied Sciences, 10, 7-23.

Ashraf, M. A., Maah, M. J., Yusoff, I., Wajid, A., \& Karama. M. (2011). Sand Mining Effects, Causes and Concerns: A Case Study from Bestari Jaya, Selangor, Peninsular Malaysia. Scientific Research and Essays, 6, 1216-1231.

Awosika, P. B., \& Papineau, M. (1993). Phase One Environmental Site Assessment, 7000 Marina Boulevard, Brisbane, California. Prepared for Argentum International by Certified, Boston, MA: Engineering \& Testing Company.

Borzée, A., Kim, K., Heo, K., Jablonski, P. G., \& Jang, Y. (2017). Impact of Land Reclamation and Agricultural Water Regime on the Distribution and Conservation Status of the Endangered Dryophytessuweonensis. Peer Reviewed and Open Access Journal Peer, 5, e3872. https://doi.org/10.7717/peerj.3872

Brunn, G. (1977). This Busy Monster: Reflections on the Consumer Society. The Journal of Consumer Affairs, 11, 1-10. https://doi.org/10.1111/j.1745-6606.1977.tb00611.x

Chauhan, S. S. (2010). Mining, Development and Environment: A Case Study of Bijolia Mining Area in Rajasthan, India. Journal of Human Ecology, 31, 65-72.

https://doi.org/10.1080/09709274.2010.11906299

Environmental Reclamation (2008). http://www.abheritage.ca/abnature/environmental/land_reclamation.htm

Folorunshom, R. (1999). Transferring a Coastal Erosion Problem: Is This a Wise Practice? Lagos-Nigeria, Wise Coastal Practices for Sustainable Human Development Forum.

Ghose, M. K. (1989). Land Reclamation and Protection of Environment from the Effect of Coal Mining Operation. Mine-Tech, 10, 35-39.

Hill, M. B., \& Webb, J. E. (1958). The Ecology of Lagos Lagoon. II. The Topography and Physical Features of Lagos Harbour and Lagos Lagoon. Philosophical Transactions of the Royal Society of London. Series B, Biological Sciences, 241, 319-333.

Hoeksema, R. J. (2007). Three Stages in the History of Land Reclamation in the Netherlands. Irrigation and Drainage Journal.

Holtz, R. D., \& Kovacs, W. D. (1981). An Introduction to Geotechnical Engineering. Prentice-Hall, Inc.

Isebor, C. E., Awosika, L., \& Smith, S. V. (2005). Preliminary Water, Salt, and Nutrient Budgets for Lagos Lagoon, Nigeria.

Lugo, A. E., Parrota, J., \& Brown, S. (1993). Loss in Species Caused by Tropical Deforestration and Their Recovery through Management. Ambio, 22, 106-109. 
Mills, R., \& Staats, E. (2016). Shrinking Shores: Florida sand Shortage Leaves Beaches in Lurch. Naples Daily News.

Mulder, E. F. J., Ajvan, B., Claessen, F. A. M., Hannink, G., Hulsbergen, J. G., \& Satijin, H. M. C. (1994). Environmental Impact Assessment on Land Reclamation Projects in Netherlands: A Case History. Engineering Geology, 37, 15-23.

https://doi.org/10.1016/0013-7952(94)90078-7

Oxford Business Group (2018). Site Designed and Built by Hydrant (2013-03-07). Depth Charges: Land Reclamation and Dredging Are Big Business. http://www.hydrant.co.uk

Perur, S. (2016). Story of Cities \#11: The Reclamation of Mumbai-From the Sea, and Its People? The Guardian.

Ratcliffe, R. (1997). Opposition to Sand Mining on Stradbroke. Green Left.

Ritchiewiki \& Wales (2016). New \& Used Heavy Equipment. https://www.ritchiespecs.com/wiki/index.php/minig\#ixzz1nWSKbm8y

USA Today (2006). Florida County Plans to Vaporize Landfill Trash.

Wallis, K. (1996). Bill Seeks to Protect Harbour. Hong Kong Standard. 